\title{
PENGARUH FIRM SIZE, LEVERAGE DAN PROFITABILITAS TERHADAP KEBIJAKAN DEVIDEN
}

Submitted Date :

2 Februari 2019

Accepted Date :

14 Februari 2019

\author{
Asri Winanti Madyoningrum \\ Sekolah Tinggi IImu Ekonomi Al-Madani \\ asri.winanti@almadani.ac.id
}

Suggested Citation:

Arilaha, Muhammad Asril. 2009. Pengaruh Free Cash Flow, Profitabilitas, Likuiditas, dan Leverage terhadap Kebijakan Dividen. Jurnal Keuangan dan Perbankan. Vol. 13. No. 1. Hal. 78-87.

\section{Abstract:}

Dividend policy of the company is reflected in the dividend payout ratio is the percentage of profits distributed in the form of cash dividends, meaning that the size of the dividend payout ratio will affect the investment decisions of shareholders, If the company's financial performance is good then the company will be able to determine the amount of the dividend payout ratio in accordance with the expectations of shareholders. The method of analysis to determine the independent variables that significantly affect the company's dividend policy at the Food and Beveragedi Indonesia Stock Exchange that Firm Size, Leverage and Profitability are:Linier Regresion. The results showed the effect of simultaneously Firm Size, leverage and profitability of the company's dividend policy at the Food and Beverage described in detail as follows: Variable Size Firm significantly influence Dividend Payout Ratio (DPR). Leverage variables significantly influence Dividend Payout Ratio (DPR). Variables significantly affect the profitability of Dividend Payout Ratio (DPR). Variable Firm Size, leverage and profitability simultaneously affect the Dividend Payout Ratio (DPR).

Keyword :Dividend Payout Ratio, Firm Size, Leverage, Profitability

\section{Abstrak :}

Kebijakan dividen perusahaan tergambar pada dividen payout rationya.yaitu presentase laba yang dibagikan dalam bentuk deviden tunai, artinya besar kecilnya dividend payout ratio akan mempengaruhi keputusan investasi para pemegang saham, Bila kinerja keuangan perusahaan bagus maka perusahaan tersebut akan mampu menetapkan besarnya dividend payout ratio sesuai dengan harapan pemegang saham. Metode analisis untuk mengetahui variabel independen yang mempengaruhi secara signifikan terhadap kebijakan deviden pada perusahaan Food and Beverage di Bursa Efek Indonesia yaitu Firm Size, Leverage dan Profitabilitas adalah:Regresi Linier Berganda. Hasil penelitian menunjukkan pengaruh secara simultan Firm Size, leverage dan profitabilitas terhadap kebijakan dividen pada perusahaan Food and Beverage yang dijelaskan secara rinci sebagai berikut :Variabel Firm Size berpengaruh secara signifikan terhadap Dividend Payout Ratio (DPR). Variabel leverage berpengaruh secara signifikan terhadap Dividend Payout Ratio (DPR). Variabel profitabilitas berpengaruh secara signifikan terhadap Dividend Payout Ratio (DPR). Variabel Firm Size, leverage dan profitabilitass secara simultan berpengaruh terhadap Dividend Payout Ratio (DPR).

Kata Kunci : Kebijakan Dividen, Profitabilitas, Rasio Hutang, Ukuran Perusahaan 


\section{Pendahuluan}

Perkembangan usaha saat ini, keefisienan serta keefektifan sebuah perusahaan akan menjadi kekuatan dalam mempertahankan usahanya serta dapat menjadi faktor yang mendukung untuk bersaing dengan para pesaing. Perusahaan dalam hal ini dihadapkan pada sebuah keputusan besar, yaitu dalam keputusan kebijakan dividen. Kebijakan ini terkait pada penggunaan laba perusahaan yang akan digunakan untuk pembagian dividen kepada para pemegang saham, atau menahan laba yang dimiliki guna dana ekspansi atau investasi yang akan datang Besarnya alokasi laba yang digunakan untuk dividen, akan menjadi perhatian bagi para investor karena tidak dapat dipungkiri, investor akan lebih menyukai nominal dividen yang besar, sedangkan hal tersebut tidak dikehendaki oleh manajemen yang lebih memilih untuk menahan laba perusahaaan dengan tujuan tertentu. (Moermahadi et al, 2009:2)

Kebijakan dividen perusahaan tergambar pada dividend payout rationya yaitu persentase laba yang dibagikan dalam bentuk deviden tunai,artinya besar kecilnya dividend payout ratio akan mempengaruhi keputusan investasi para pemegang saham Kebijakan dividen merupakan bagian yang tidak dapat dipisahkan dengan keputusan pendanaan perusahaan. Kebijakan dividen (dividend policy) merupakan keputusan apakah laba yang diperoleh perusahaan pada akhir tahun akan dibagi kepada pemegang saham dalam bentuk dividen atau akan ditahan untuk menambah modal guna pembiayaan investasi di masa yang akan datang

Perusahaan yang memiliki rasio utang lebih besar seharusnya membagikan dividen lebih kecil karena laba yang diperoleh digunakan untuk melunasi kewajiban. Utang jangka panjang diikat oleh sebuah perjanjian utang untuk melindungi kepentingan kreditor. . Untuk itu, semakin tinggi rasio utang/ekuitas, maka semakin ketatnya perusahaan terhadap perjanjian utang. Kaitannya dengan pembayaran dividen, maka dapat dikatakan semakin tinggi rasio utang/ekuitas, pembayaran dividen akan semakin kecil

Dari Proporsi Net Income After Tax yang dibagikan sebagai dividen biasanya dipresentasikan dalam Dividend Payout Ratio (DPR). Dividend Payout Ratio inilah yang menentukan besarnya dividen per lembar saham (DividendPerShare). Jika dividen yang dibagikan besar maka hal tersebut akan meningkatkan harga saham yang juga berakibat pada peningkatan nilai perusahaan. Diviend payout ratio merupakan perbandingan antara dividend per share dengan earning per share. Di dalam komponen Dividend per share terkandung unsur dividen, sehingga jika semakin besar dividend yang dibagikan maka semakin besar dividend payout rationya.( (Miller danModigliani dalam Husnan, 2009)

Dari uraian di atas dapat disimpulkan bahwa kebijakan deviden erat kaitannya dengan variabel variabel lain dalam suatu perusahaan tersebut. Profitabilitas yang tinggi biasanya akan mendorong suatu perusahaan mengeluarkan kebijakan deviden. Besarnya dividen yang dibagikan tergantung pada kebijakan dividen masingmasing perusahaan.

Berikut ini Presentase Ukuran Perusahaan, Leverage, Profitabilitas dan Kebijakan Deviden Perusahaan Food and Beverage tahun 2014 dapat dilihat dalam tabel berikut ini 
Tabel 1. Persentase Firm Size, Leverage, Profitabilitas dan kebijakan Dividen Perusahaan Foodand Beverage Tahun 2014

\begin{tabular}{rlcccc}
\hline \multirow{2}{*}{ No NamaPerusahaan } & \multicolumn{2}{c}{ Size } & Leverage & Profitabilitas & DPR \\
\cline { 3 - 5 } & & $(R p)$ & $(\%)$ & $(\%)$ & $(\%)$ \\
\cline { 3 - 5 } & & & & & \\
\cline { 3 - 5 } & & $\mathbf{2 0 1 4}$ & $\mathbf{2 0 1 4}$ & $\mathbf{2 0 1 4}$ & $\mathbf{2 0 1 4}$ \\
\hline 2 & PT Akasha Wira Internasional & 13,35 & 0,40 & 27,17 & 19,58 \\
3 & PT Cahaya Kalbar Tbk & 14,45 & 0,41 & 13,09 & 0,22 \\
4 & PT Delta Djakarta Tbk & 15,90 & 0,56 & 28,03 & 0,01 \\
5 & PT Indofood Sukses makmur Tbk & 16,98 & 0,41 & 10,22 & 33,32 \\
6 & PT Multi Bintang Indonesia Tbk & 12,71 & 0,37 & 16,65 & 73,93 \\
7 & PT Mayora Indah Tbk & 12,02 & 0,56 & 1,33 & 31,39 \\
8 & PT Prasidha Aneka Niaga Tbk & 13,28 & 0,25 & 17,60 & 39,50 \\
9 & PT Sekar Bumi Tbk & 13,96 & 0,70 & 10,02 & 21,42 \\
10 & PT Sekar laut Tbk & 14,25 & 0,30 & 4,38 & 72,42 \\
11 & PT Siantar Top Tbk & 15,02 & 0,74 & 27,17 & 40,42 \\
12 & PT Ultrajaya Milk Tbk & 16,38 & 0,55 & 26,04 & 28,65 \\
\hline & Total & 14,72 & 0,15 & 31,93 & 57,57 \\
\hline & Rata-rata & 173,02 & 5,4 & 213,63 & 418,426 \\
\hline
\end{tabular}

Sumber : www.idx.co.id

Dari hasil Tabel 1 menunjukkan bahwa pada perusahaan Food and Beverage memiliki size rata-rata sebesar 14,42 dan hanya dua perusahaan yang berada dibawah rata-rata. Leverage pada perusahaan Food and Beverage memiliki nilai yang beragam, dan memiliki nilai rata-rata sebesar $0,45 \%$, sedangkan Profitabilitas pada perusahaan Food and Beverages memiliki nilai rata-rata yaitu sebesar $17,80 \%$. Tabel 1 juga menunjukkan adanya rasio pembayaran dividen yaitu dengan rasio pembayaran dividen yang hanya mencapai 34,87 yang berarti bahwa pembagian dividen belum maksimal atau kurang dari 50\% (Sudana, 2011) dan adanya perbedaan hasil penelitian terdahulu, maka perlu diteliti lebih lanjut pengaruh variabel Firm Size, Leverage dan Profitabilitas terhadap kebijakan dividend payout ratio pada perusahaan Food and Beverages yang terdaftar di Bursa Efek Indonesia periode 2000-2014.

Tujuan penelitian adalah (1) untuk mengetahui pengaruh Firm Size Terhadap kebijakan deviden pada Perusahaan Food and Beverage yang terdaftar di BEI Tahun 2000-2014. (2) Untuk mengetahui pengaruh Leverage Terhadap Kebijakan deviden pada Perusahaan Food and Beverage yang terdaftar di BEI Tahun 20002014.(3) Untuk mengetahui pengaruh profitabilitas Terhadap Kebijakan deviden pada Perusahaan Food and Beverage yang terdaftar di BEI Tahun 2000-2014.(4) Untuk mengetahui pengaruh Firm Size, Leverage dan profitabilitas terhadap Kebijakan deviden pada Perusahaan Food and Beverage yang terdaftar di BEI Tahun 2000-2014.

\section{Metode Penelitian dan Hipotesis}

Dalam penelitian ini menjelaskan pengaruh variabel bebas yaitu Firm size ( X1), Leverage (X2), dan Profitabilitas (X3) terhadap Kebijakan Deviden (Y). Obyek penelitian yang digunakan oleh peneliti adalah Perusahaan Food and Beverage yang terdaftar di Bursa Efek Indonesia Tahun 2000-2014. Model analisis yang digunakan dalam penelitian ini menggunakan regresi linier berganda. Metode analisis ini untuk mengetahui variabel independen yang mempengaruhi secara signifikan terhadap kebijakan deviden pada perusahaan Food and Beverage di Bursa Efek Indonesia yaitu Firm Size, Leverage, dan Profitabilitas adalah : 


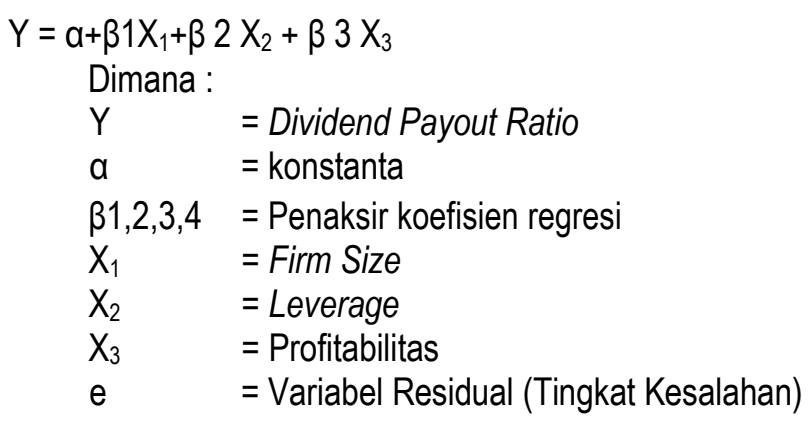

Populasi dalam penelitian ini adalah Perusahaan Food and Beverage yang terdaftar di Bursa Efek Indonesia. Teknik pengambilan sampel menggunakan metode purposive sampling. Kriteria-kriteria yang digunakan dalam penelitian ini adalah sebagai berikut:

1. Jenis Perusahaan adalah Perusahaan Food and Beverage yang go public terdaftar di Bursa efek Indonesia Tahun 2000-2014.

2. Memiliki laporan keuangan yang lengkap Tahun 2000-2014.

3. Perusahaan Food and Beverage tidak mengalami kerugian selama tahun 2000-2014.

4. Perusahaan membayarkan dividen secara kontinyu selama periode pengamatan periode 2000-2014.

Sampel yang digunakan dalam penelitian sebagai berikut:

Tabel 2. Sampel dalam Penelitian

\begin{tabular}{lll}
\hline No & Kode Emiten & Nama Emiten \\
\hline 1 & ADES & PT Akasha Wira Internasional Tbk \\
\hline 2 & AISA & PT Tiga Pilar Sejahtera Tbk \\
\hline 3 & CEKA & PT Cahaya Kalbar Tbk \\
\hline 4 & DLTA & PT Delta Djakarta Tbk \\
\hline 5 & INDF & PT Indofood Sukses makmur Tbk \\
\hline 6 & MLBI & PT Multi Bintang Indonesia Tbk \\
\hline 7 & MYOR & PT Mayora Indah Tbk \\
\hline 8 & PSDN & PT Prasidha Aneka Niaga Tbk \\
\hline 10 & SKBM & PT Sekar Bumi Tbk \\
\hline 11 & SKLT & PT Sekar laut Tbk \\
\hline 12 & ULTJ & PT Siantar Top Tbk \\
\hline
\end{tabular}

Data yang digunakan dalam penelitian ini adalah data sekunder, yaitu data yang diterbitkan oleh lembaga, dalam hal ini adalah Bursa Efek Indonesia (BEI), yaitu berupa data laporan keuangan Perusahaan Food and Beverage Tahun 2000-2014 (www. idx. co. id)

\section{Definisi operasional variabel Variabel Dependen $(Y)$}

Variabel dependen dalam penelitian ini adalah kebijakan deviden (Dividend Policy) adalah keputusan apakah laba yang diperoleh perusahaan dibagikan kepada pemegang saham sebagai deviden atau ditahan dalam bentuk laba guna pembayaran investasi dimasa yang akan datang (Sartono 2000) yang dapat diukur dengan Dividend Payout Ratio (DPR) .

Devidend Payout Ratio $(\mathrm{DPR})=\frac{\text { Dividend Per Share }}{\text { Earning Per Share }}$ 


\section{Variabel Independen $(X)$}

Variabel-Variabel Independen dalam penelitian ini adalah sebagai berikut:

a. Firm Size (X1)

Ukuran perusahaan (size) merupakan salah satu variabel yang banyak digunakan untuk menjelaskan mengenai variasi pengungkapan dalam laporan tahunan perusahaan. Terdapat beberapa penjelasan mengenai pengaruh ukuran perusahaan (size) terhadap kualitas ungkapan. Ukuran perusahaan menggambarkan besar kecilnya suatu perusahaan yang ditunjukkan oleh total asset, jumlah penjualan, rata-rata tingkat penjualan dan rata-rata total asset. Ukuran perusahaan diwakili oleh Log Natural $(\mathrm{LN})$ dari total assets tiap tahun, ukuran perusahaan $=$ Ln Total Assets (Kusuma, 2005:83)

Perusahaan yang sudah besar atau mapan cenderung untuk memberi tingkat pembayaran dividen yang lebih tinggi daripada perusahaan kecil atau baru (Weston dan Copeland, 1996:100). Perusahaan yang memiliki ukuran perusahaan besar akan lebih mudah memasuki pasar modal sehingga dengan kesempatan ini perusahaan membayar dividen besar kepada pemegang saham (Kartika, 2005).

Ferry dan Jones (dalam Sujianto, 2001), ukuran perusahaan menggambarkan besar kecilnya suatu perusahaan yang ditunjukkan oleh total aktiva, jumlah penjualan, rata-rata total penjualan dan rata-rata total aktiva. Jadi rata-rata perusahaan merupakan ukuran atau besarnya aset yang dimiliki oleh perusahaan. Ukuran perusahaan (Firm Size) merupakan ukuran atau besarnya aktiva yang dimiliki perusahaan yang dapat di proxy dengan nilai logaritma dari total aktiva Firm Size $=\operatorname{Ln}$ (Total Assets) (Hadri Kusuma, 2005:83).

\section{b. Leverage $(\mathrm{X} 2)$}

Solvabilitas (Leverage) digambarkan untuk melihat sejauh mana asset perusahaan dibiayai oleh hutang dibandingkan dengan modal sendiri (Weston dan Copeland,1992). Leverage adalah suatu tingkat kemampuan perusahaan dalam menggunakan aktiva dan atau dana yang mempunyai beban tetap (hutang dan atau saham istimewa) dalam rangka mewujudkan tujuan perusahaan untuk memaksimisasi kekayaan pemilik perusahaan. Perusahaan yang memiliki rasio utang lebih besar seharusnya membagikan dividen lebih kecil karena laba yang diperoleh digunakan untuk melunasi kewajiban. Semakin tinggi rasio utang/ekuitas, maka semakin ketatnya perusahaan terhadap perjanjian utang. Kaitannya dengan pembayaran dividen, maka dapat dikatakan semakin tinggi rasio utang/ekuitas, pembayaran dividen akan semakin kecil.

Rasio hutang modal/Debt to Equity Ratio merupakan perbandingan antara total hutang (hutang lancar dan hutang jangka panjang) dan modal yang menunjukkan kemampuan perusahaan untuk memenuhi kewajibannya dengan menggunakan modal yang ada (Riyanto, 2008:22)

Rasio hutang modal dihitung dengan formula:

$$
\text { Debt to equity ratio }=\frac{\text { Toatal Hutang }}{\text { Modal (equity) }}
$$

c. Profitabilitas $\left(X_{3}\right)$

Profitabilitas merupakan kemampuan perusahaan memperoleh laba dalam hubungannya dengan penjualan, total aset maupun modal sendiri (Sartono 2001). Rasio profitabilitas sangat bermanfaat bagi kelangsungan perusahaan karena dapat membantu perusahaan untuk mengetahui kontribusi keuntungan perusahaan dalam jangka pendek atau jangka panjang (Hanafi dan Halim, 2005:85).

Rasio profitabilitas merupakan rasio yang digunakan untuk mengukur efektifitas manajemen berdasarkan hasil pengembalian dari penjualan investasi serta kemampuan perusahaan menghasilkan laba yang akan menjadi dasar pembagian dividen perusahaan (Gitman, 2003:147) 
Profitabilitas perusahaan dapat diproyeksikan melalui return on asset (ROA). ROA merupakan suatu ukuran menyeluruh dari prestasi perusahaan, sebab rasio ini menunjukkan laba atas seluruh dana yang diinvestasikan. Profitabilitas perusahaan memiliki pengaruh positifterhadap kebijakan dividen. Semakin tinggi profitabilitas perusahaan, maka semakin tinggi pula arus kas dalam perusahaan dan diharapkan perusahaan akan membayar dividen yang lebih tinggi (Jensen, Solberg dan Zorn,1992) seperti dikutip Fitri Ismiyanti dan Mahadwartha (2005).

Return On Assets $(\mathrm{ROA})=\frac{\text { Laba Bersih }}{\text { Total Assets }}$

\section{Pengaruh Firm Size terhadap kebijakan deviden pada perusahaan}

Hasil penelitian Handayani dan Hadinugroho (2009) menunjukkan bahwa size berpengaruh signifikan terhadap kebijakan dividen karena Perusahaan yang memiliki ukuran yang besar akan lebih mudah memasuki pasar modal sehingga dengan kesempatan ini perusahaan membayar dividen dengan jumlah besar kepada pemegang saham.Ukuran perusahaan merupakan simbol ukuran perusahaan yang berhubungan dengan peluang dan kemampuan untuk masuk ke pasar modal dan jenis pembiayaan eksternal lainnya yang menunjukkan kemampuan meminjam. Hal ini menunjukkaan hubungan, bahwa semakin besar ukuran perusahaan maka semakin besar pula dividen yang akan dibagikan.

Hipotesis yang diajukan dalam penelitian ini adalah:

\section{$\mathbf{H}_{1}$ : Firm Size berpengaruh terhadap kebijakan deviden pada perusahaan Food and Beverage}

\section{Pengaruh Leverage terhadap kebijakan deviden pada perusahaan}

Leverage merupakan besar kebutuhan dana perusahaan yang dibelanjai dengan hutang.Jika tingkat leverage bernilai nol maka perusahaan tidak menggunakan pendanaan perusahaan dengan hutang Leverage yang semakin tinggi akan menyebabkan kebijakan inisiasi dividen semakinmenurun, begitu pula sebaliknya semakin rendah leverage yang digunakan oleh perusahaan karena menipisnya hutang yang dibayarkan maka laba yang didapatkan semakin meningkat. Hardianto dan Herlina (2010) perusahaan yang tidak membayar dividen diprediksi memiliki rasio hutang yang tinggi karena harus berkonsentrasi dalam membayar bunga dan pokok pinjamannya, sedangkan perusahaan yang membayar dividen diperkirakan memiliki rasio hutang yang rendah.

Berdasarkan uraian tersebut, maka peneliti menduga bahwa Leverage berpengaruh terhadap kebijakan inisiasi dividen. Hipotesis yang diajukan dalam penelitian ini adalah:

\section{$\mathbf{H}_{2}$ :Leverage berpengaruh terhadap Kebijakan deviden Perusahaan Food and Beverage.}

\section{Pengaruh Profitabilitas terhadap kebijakan deviden pada perusahaan}

Rasio Profitabilitas merupakan rasio yang mengukur seberapa besar tingkat keuntungan yang dapat diperoleh perusahaan. Rasio profitabilitas diproksikan dengan Return On Asset (ROA). ROA mampu mengukur profitabilitas perusahaan terhadap jumlah dana investasi. Return on Asset dinilai dari kemampuan perusahaan dalam kepemilikan modal yang diinvestasikan pada total aktiva untuk menghasilkan laba. Laba atau keuntungan yang dihasilkan dibagikan kepada para pemegang saham dalam bentuk dividen, baik dividen tunai maupun dividen saham tergantung kesepakatan manajer dan investor perusahaan. Semakin tinggi tingkat ROA maka pembagian dividen akan semakin banyak bagi para investor. Chen dan Steiner dalam Dewi (2008) semakin tinggi laba, maka semakin tinggi pula cash flow dalam perusahaan, maka diharapkan perusahaan akan membayarkan dividen yang tinggi. Berdasarkan uraian tersebut, maka peneliti menduga bahwa Return On Asset (ROA) berpengaruh positif terhadap kebijakan inisiasi dividen.

\section{$\mathrm{H}_{3}$ :Profitabilitas berpengaruh terhadap Kebijakan deviden Perusahaan Food and Beverage}




\section{Pengaruh Firm Size, Leverage dan Profitabilitas terhadap kebijakan deviden Perusahaan}

Variabel ukuran perusahaan (size) dinyatakan berpengaruh signifikan terhadap kebijakan dividen (dividend payout ratio) pada penelitian Handayani dan Hadinugroho (2009), namun kontradiktif dengan hasil penelitian Chasanah (2008) menyatakan bahwa ukuran perusahaan (size) tidak berpengaruh signifikan terhadap kebijakan dividen (dividend pay out ratio). Variabel leverage (debt to equity ratio) dinyatakan berpengaruh signifikan terhadap kebijakan dividen (dividend payout ratio) pada penelitian Karami (2013) dan Asif et.al (2011), namun kontradiktif dengan hasil penelitian Arilaha (2009) dimana leverage (debt to equity ratio) tidak berpengaruh signifikan.Variabel profitabilitas (return on asset) dinyatakan berpengaruh positif dan signifikan terhadap kebijakan dividen (dividend payout ratio) pada penelitian Parica, dkk (2013) dan Arilaha (2009), namun kontradiktif dengan hasil penelitian Sulistiyowati, et.al (2010) yang menyatakan bahwa profitabilitas (return on investment) tidak berpengaruh signifikan terhadap kebijakan dividen (dividend payout ratio).

Hipotesis yang diajukan dalam penelitian ini adalah

$\mathrm{H}_{4}$ : Firm Size, Leverage dan Profitabilitas berpengaruh terhadap kebijakan deviden Perusahaan Food and Beverage

Berdasarkan hubungan antar variabel tersebut, maka dapat disusun keragka konsep sebagai berikut :

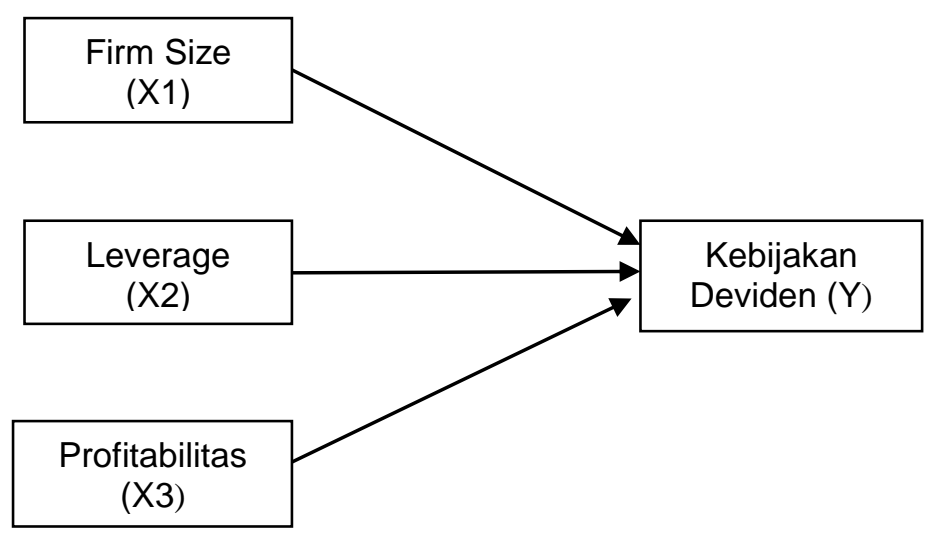

Gambar 1. Model Kerangka konseptaul

\section{Hasil Penelitian}

Pengaruh variabel Firm Size, Leverage dan profitabilitas terhadap Dividend Payout Ratio, terlebih dahulu akan ditinjau mengenai deskripsi variabel penelitian dengan analisis statistik deskriptif. Statistik deskriptif memberikan gambaran suatu data yang dapat dilihat dari nilai rata-rata (mean), standar deviasi, nilai maksimum dan minimum. Selengkapnya mengenai hasil statistik deskriptif penelitian dapat dilihat pada Tabel 3 sebagai berikut: 
Tabel 3. Statistik Deskriptif Variabel Yang Digunakan

Descriptive Statistics

\begin{tabular}{lrrrrr}
\hline & N & \multicolumn{1}{c}{ Minimum } & Maximum & \multicolumn{1}{c}{ Mean } & \multicolumn{1}{c}{ Std. Deviation } \\
\hline Firm_size & 180 & 12.020 & 17.020 & 14.24333 & 1.609479 \\
Leverage & 180 & .150 & .740 & .44000 & .162876 \\
Profitabilitas & 180 & 1.330 & 31.930 & 16.84000 & 9.958964 \\
Kebijakan_dividen & 180 & .010 & 73.930 & 34.68667 & 23.260543 \\
Valid N (listwise) & 180 & & & & \\
\hline
\end{tabular}

Sumber : Data Diolah dengan SPSS 17.00

Dari hasil pengolahan data pada Tabel 3 diketahui bahwa variabel Firm Size yang merupakan Log Natural dari Total Aset menunjukkan mean sebesar 14,44 Sedangkan nilai maksimumnya adalah 17,02 dan nilai minimumnya 12,02 Nilai mean variabel leverage sebesar 0,44 . Sedangkan nilai maksimumnya adalah 0,74 dan nilai minimumnya 0,15 yang berati bahwa kemampuan perusahaan untuk membayar hutangnya denganmenggunakan ekuitas yangdimilikinya sebesar 0,44. Nilai mean variabel profitabilitas sebesar 16,84. Sedangkan nilai maksimumnya adalah 31,930 dan nilai minimumnya 1,33 , yang berati bahwa kemampuan perusahaan memperoleh laba dalam hubungannya dengan penjualan, total aset maupun modal sendiri sebesar 16,84. Kebijakan deviden dengan rasio Dividend Payout Ratio (DPR) diperoleh mean sebesar 34,68 . Hal ini berarti bahwa rata-rata kebijakan pembagian dividen tunai adalah sebesar $34,68 \%$ dari laba per lembar saham yang diperoleh perusahaan. Nilai maximum sebesar 73,93 sedangkan nilai minimum DPR adalah 0,010 dari laba per lembar saham yang diperoleh, dengan demikian kondisi keputusan investasi yang given, pembayaran dividen tidak berpengaruh terhadap kemakmuran pemegang saham sebesar $34,68 \%$.

\section{Persamaan Regresi Linier Berganda}

Berdasarkan hasil engolahan data, maka dapat didiketahui bahwa persamaan regresi linier berganda yang dihasilkan adalah sebagai berikut: $D P R=98,381+0,908 X_{1}+0,918 X_{2}+0,423 X 3$

Persamaan regresi dapat diinterpretasikan sebagai berikut:

1. Koefisien konstanta sebesar 98,381 dengan nilai positif, ini dapat diartikan bahwa kebijakan dividen (DPR) akan bernilai 98,381 apabila masing-masing variabel Firm Size, leverage dan profitabilitas bernilai 0 .

2. Variabel Firm Size memiliki koefisien regresi sebesar 0,906. Nilai koefisien regresi positif menunjukkan bahwa Firm Size berpengaruh positif terhadap kebijakan dividen. Hal ini menggambarkan bahwa jika setiap kenaikan satu persen variabel Firm Size, dengan asumsi variabel lain tetap maka akan menaikkan kebijakan dividen sebesar 0,906.

3. Variabel leverage memiliki koefisien regresi sebesar 0,918. Nilai koefisien regresi positif menunjukkan bahwa leverage berpengaruh positif terhadap kebijakan dividen. Hal ini menggambarkan bahwa jika setiap kenaikan satu persen variabel leverage, dengan asumsi variabel lain tetap maka akan menaikkan kebijakan dividen sebesar 0,918 .

4. Variabel profitabilitas memiliki koefisien regresi sebesar 0,423 . Nilai koefisien regresi positif menunjukkan bahwa profitabilitas berpengaruh positif terhadap kebijakan dividen. Hal ini menggambarkan bahwa jika setiap kenaikan satu persen variabel profitabilitas, dengan asumsi variabel lain tetap maka akan menaikkan kebijakan dividen sebesar 0,423 .

\section{Uji F}

Berdasarkan hasil uji F -Statistik yang ditunjukan oleh Tabel 4. Hasil Uji Statistik F diketahui bahwa variabel independen yaitu Firm Size, Leverage dan Profitabilitas secara simultan atau bersama-sama mampu menjelaskan perubahan pada variabel dependen yaitu Dividend Payout Ratio (DPR) dengan tingkat signifikan 
sebesar 0,027 yang lebih kecil dari $0,05(\mathrm{a}=0,05)$. Maka dapat disimpulkan bahwa terdapat pengaruh simultan yang signifikan antara Firm Size, Leverage dan Profitabilitas terhadap DPR.

Tabel 4. Hasil Uji Statistik F

\begin{tabular}{llrrrrr}
\multicolumn{7}{c}{ ANOVA $^{\mathrm{b}}$} \\
\hline Model & & Sum of Squares & \multicolumn{1}{c}{ df } & Mean Square & \multicolumn{1}{l}{ F } & Sig. \\
\hline 1 & Regression & 2184.553 & 3 & 728.184 & 10.486 & $.0^{\text {a }}$ \\
& Residual & 5390.187 & 173 & 490.017 & & \\
& Total & 7574.740 & 180 & & & \\
\hline
\end{tabular}

a. Predictors: (Constant), Profitabilitas, Leverage, Firm_size

b. Dependent Variable: Kebijakan_dividen

Sumber: data diolah dengan SPSS 17. 00

\section{Koefisien Determinasi $\left(\mathbf{R}^{2}\right)$}

Tabel 4.3 menunjukkan nilai $R^{2}$ adalah sebesar 0,543 . Hal ini berarti bahwa sebesar $54,3 \%$ variabel dependen atau DPR dipengaruhi oleh variabel independen yaitu Firm Size, leverage dan profitabilitas. Sedangkan sisanya yaitu sebesar $45,7 \%$ dijelaskan oleh faktor-faktor lain yang dapat mempengaruhi $D P R$.

Tabel 5. Koefisien Determinasi

Model Summary

\begin{tabular}{lrrrr}
\hline Model & R & R Square & Adjusted R Square & $\begin{array}{c}\text { Std. Error of the } \\
\text { Estimate }\end{array}$ \\
\hline 1 & $.737^{\mathrm{a}}$ & .543 & .094 & 22.136327 \\
\hline
\end{tabular}

a. Predictors: (Constant), Profitabilitas, Leverage, Firm_size

Sumber: data diolah dengan SPSS 17.00

\section{Uji T}

Uji ini digunakan untuk menguji pengaruh dari seluruh variabel independen secara parsial terhadap variabel dependen. Hasil uji $t$ dapat dilihat dari nilai signifikansi Firm Size, leverage dan profitabilitas dalam menerangkan variabel dependen, yaitu Dividend Payout Ratio (DPR). Dari hasil uji T statistisk yang terdapat dalam Tabel 4.4 menunjukkan bahwa menunjukkan nilai thitung untuk variabel Firm Size $=6,475>r_{\text {tabel }}=1,653$ yang berarti bahwa secara parsial Firm Size berpengaruh terhadap Kebijakan deviden pada perusahaan Food and Beverage yang terdaftar di BEI Tahun 2000-2014. Kemudian $t_{\text {hitung }}$ untuk variabel leverage $=8,813>r_{\text {tabel }}=$ 1,653 yang berarti bahwa secara parsial leverage berpengaruh terhadap Kebijakan deviden pada perusahaan Food and Beverage yang terdaftar di BEI Tahun 2000-2014. Kemudian thitung untuk variabel profitabilitas $=4,653$ $>r_{\text {tabel }}=1,653$ yang berarti bahwa secara parsial profitabilitas berpengaruh terhadap Kebijakan deviden pada perusahaan Food and Beverage yang terdaftar di BEI Tahun 2000-2014.

\section{Pembahasan}

\section{Pengarh Firm Size terhadap Kebijakan Deviden}

Hasil penelitian menunjukkan thitung untuk variabel Firm Size $=6,475>r_{\text {tabel }}=1,653$ yang berarti bahwa secara parsial Firm Size berpengaruh terhadap Kebijakan deviden pada perusahaan Food and Beverage yang 
terdaftar di BEI Tahun 2000-2014. Variabel Firm Size, leverage dan profitabilitas secara simultan atau bersamasama mampu menjelaskan perubahan pada variabel dependen yaitu dividend payou tratio (DPR). Hal ini dapat dilihat dari tingkat signifikan sebesar 0,027 yang lebih kecil dari $0,05(\mathrm{a}=0,05)$. Maka dapat disimpulkan bahwa terdapat pengaruh simultan yang signifikan antara Firm Size, terhadap DPR Dengan demikian Ho ditolak dan $\mathrm{Ha}$ diterima. Hal ini sesuai dengan Hasil penelitian Handayani dan Hadi nugroho (2009) menunjukkan bahwa size berpengaruh signifikan terhadap kebijakan dividen

\section{Pengaruh Leverage terhadap kebijakan Deviden}

Hasil penelitian menunjukkan variabel Firm Size, leverage dan profitabilitas secara simultan atau bersama-sama mampu menjelaskan perubahan pada variabel dependen yaitu dividend payout ratio (DPR). Hal ini dapat dilihat dari nilai Fhitung $(10,486)$ dengan tingkat signifikan sebesar 0,027 yang lebih kecil dari 0,05( $\mathrm{a}=0,05$ ). Maka dapat disimpulkan bahwa terdapat pengaruh yang signifikan leverage terhadap DPR. Hasil penelitian Karami (2013) dan Asif et.al (2011) menyatakan bahwa rasio hutang dengan modal (debt to equity ratio) memiliki hubungan yang signifikan terhadap dividend payout ratio. Hasil penelitian Suharli dan Megawati dalam Arilaha (2009) yang menunjukkan bahwa perusahaan yang leverage operasi atau keuangannya tinggi akan memberikan dividen yang rendah. Berdasarkan uraian di atas, maka menurut peneliti perusahaan yang memiliki rasio hutang lebih besar akan membagikan dividen lebih kecil karena laba yang diperoleh digunakan untuk melunasi kewajiban. Hutang jangka panjang diikat oleh sebuah perjanjian hutang untuk melindungi kepentingan kreditor.

\section{Pengaruh Profitabilitas terhadap kebijakan deviden}

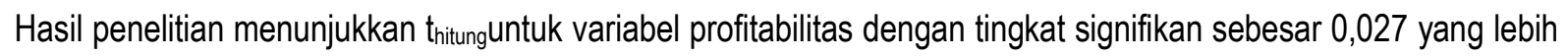
kecil dari $0,05(\alpha=0,05)$ yang berarti bahwa secara parsial profitabilitas berpengaruh terhadap Kebijakan deviden pada perusahaan Food and Beverage yang terdaftar di BEI Tahun 2000-2014. Variabel Firm Size, Leverage dan Profitabilitas secara simultan atau bersama-sama mampu menjelaskan perubahan pada variabel dependen yaitu Dividend Payout Ratio (DPR). Hal ini dapat dilihat dari nilai Fhitung $(10,486)$. Maka dapat disimpulkan bahwa terdapat pengaruh simultan profitabilitas terhadap DPR. Dengan demikian Ho ditolak dan Ha3 diterima, dimana Ha3 adalah bahwa variabel Return On Assets akan berpengaruh secara signifikan terhadap Dividend Payout Ratio. Adapun nilai beta sebesar $(0,410)$ sehingga Return on Assets mempunyai pengaruh positif terhadap Dividend Payout Ratio. Artinya, perolehan laba yang tinggi dapat meningkatkan pembayaran dividen yang tinggi pula.

Penelitian ini sesuai dengan penelitian yang dilakukan oleh Arilaha (2009) yang menyatakan bahwa besar kecilnya laba perusahaan akan mempengaruhi besar kecilnya pembagian dividen. Apabila laba perusahaan besar berarti dividen yang dibagikan akans emakin besar pula ,demikian pula sebaliknya . Perusahaan yang memiliki stabilitas keuntungan dapat menetapkan tingkat pembayaran dividen dengan yakin dan mensinyalkankualitas atas keuntunganmereka.

\section{Kesimpulan}

Hasil penelitian menunjukkan pengaruh secara simultan Firm Size, leverage dan profitabilitas terhadap kebijakan dividen pada perusahaan Food and Beverage yang dijelaskan secara rinci sebagai berikut: (1) Variabel Firm Size berpengaruh secara signifikan terhadap Dividend Payout Ratio (DPR pada Perusahaan Food and Beverage yang terdaftar di BEI Tahun 2000-2014. (2) Variabel leverage berpengaruh secara signifikan terhadap Dividend Payout Ratio (DPR) pada Perusahaan Food and Beverage yang terdaftar di BEl tahun 2000-2014. (3) Variabel profitabilitas berpengaruh secara signifikan terhadap Dividend Payout Ratio (DPR) pada Perusahaan Food and Beverage yang terdaftar di BEI tahun 2000-2014. (4) Variabel Firm Size, leverage dan profitabilitas secara simultan berpengaruh terhadap Dividend Payout Ratio (DPR) pada Perusahaan food and Beverage yang terdaftar di BEl tahun 2000-2014 


\section{Daftar Pustaka}

Arilaha, Muhammad Asril. 2009. Pengaruh Free Cash Flow, Profitabilitas, Likuiditas, dan Leverage terhadap Kebijakan Dividen. Jurnal Keuangan dan Perbankan. Vol. 13. No. 1. Hal. 78-87.

Bambang Riyanto. 2008. Dasar-dasar Pembelanjaan Perusahaan. Yogyakarta: Penerbit GPFE

Chasanah, Amalia N. 2008. Faktor-Faktor Yang Mempengaruhi Dividend Payout Ratio (DPR) Pada Perusahaan Yang Listed Di Bursa Efek Indonesia. Universitas Diponegoro Semarang. Tesis

Dewi, Sisca Christianty. 2008. Pengaruh Kepemilikan Manajerial, Kepemilikan Institusional, Kebijakan Hutang,

Profitabilitas dan Ukuran Perusahaan Terhadap Kebijakan Deviden. Jurnal Bisnis dan Akuntansi Vol. 10, No.1

Djanegara. H. Moermahadi S. Triandi dan Skundita Prakitno. 2009. Studi Tentang Peranan Audit Operasional dalam Meningkatkan Efektivitas dan Efisiensi Fungsi Pembelian pada PT. Organ Jaya. Jurnal IImiah Ranggagading, Volume IX Nomor 1, hal. 1-8

Gitman, Lawrence J. 2003. Fundamental of Investing International. 10 th ed, International Editions Financial Series. Boston: Addison-Wesley

Hanafi, Mamduh dan Abdul Halim. 2005. Analisis Laporan Keuangan. Edisi Kedua,Yogyakarta: YKPN

Handayani, D.R. dan Hadinugroho, B. 2009. Analisis Pengaruh Kepemilikan Manajerial, Kebijakan Hutang, ROA, Ukuran Perusahaan terhadap Kebijakan Dividen.Jurnal Fokus Manajerial. Vol.7, No.1, Hal.64-71.

Hardianto dan Herlina. 2010. Prediksi Arus Kas Bebas,Kebijakan Utang,dan Profitabilitas terhadap Kemungkinan Dibayarkanya Dividen.Jurnal Manajemen Bisnis. No 1. Volume 3. Hal 53 -74.

Imran, Kashif. 2011. Determinaants of Dividend Payout Policy. 4 Case Of Pakistan Enginering Sector. The Romanian Economic Journal No. 41. Year X1V. p 47-60.

Ismiyanti,Fitri dan Mahadwartha. 2005. Kepemilikan Manajerial, Kepemilikan Institusional, Risiko, Kebijakan Utang dan Kebijakan Dividen: Analisis Persamaan Simultan. Simposium Nasional Akuntansi VI. Surabaya.

Jensen, Solberg and Zorn. 1992. Simultaneous Determination of Inside Ownership, Debt and Dividend Policie, Journal of Financial and Quantitative Analysi. , Vol 27, No. 2. HIm: 247-263

Karami, Lalu Candra. 2013. "The Influence of Leverage and Liquidity on Dividend Policy" (Empirical Study on Listed Companies in Indonesia Stock Exchange of LQ45 in 2011-2010)

Kusuma, Hadri, 2005, Faktor-Faktor yang mempengaruhi Struktur Modal Pada Perusahaan Manufaktur Go Publick yang terdaftar di Bursa Efek Jakarta. Sinergi, Edisi Khusus on Finance

Miller,M.H.dan Modigliani,F.2009.Dividend Policy,Growth and the valuation of shares.Journal of Business .Vol.34.pp. 411-433

Parica, Roni dkk. 2013. Pengaruh Laba Bersih, Arus Kas Operasi, Likuiditas, dan Profitabilitas terhadap Kebijakan Dividen Pada Perusahaan Automotive and Allied Product yang terdaftar di BEl. Jurnal Akuntansi Universitas Riau Vol.2 No.1

Sartono, Agus 2000. Manajemen Keuangan, Teori dan Aplikasi.Edisi Kedua.Yogyakarta: BPFE UGM.

Sartono, Agus. 2001. Manajemen Keuangan Teori dan Aplikasi. Edisi Keempat. Yogyakarta: BPFE-Yogyakarta.

Sudana, 2011, Manajemen Keuangan Perusahaan Teori dan Praktek. Erlangga, Jakarta.

Sujianto,. 2001. Analisis Variabel -Variabel Yang Mempengaruhi Struktur Keuangan Pada Perusahaan Manufaktur Yang Go Public di Bursa Efek Jakarta. Jurnal Ekonomi dan Manajemen. Vol.2.No.2.

Sulistiyowati, et. al. 2010. Pengaruh profitabilitas, Leverage, dan growth terhadap kebijakan dividen dengan good corporate governance sebagai variabel lintervening. SNA XIII Purwokerto .

Weston J. Fred dan Thomas E. Copeland. 1992. Manajemen Keuangan Jilid II. Terjemahan Yohanes Lamarto. Jakarta : Erlangga

Weston, J. Fred dan Thomas E. Copeland. 1996. Manajemen Keuangan Edisi Kedelapan Jilid 2. Jakarta: Erlangga

www.idx.co.id 